\title{
Tajemnice labiryntów. \\ Geneza, znaczenie i perspektywy dla arteterapii
}

\section{KEY WORDS}

labyrinth, maze, identity, art therapy, horticultural therapy, garden therapy

\begin{abstract}
Stępak Jędrzej, Tajemnice labiryntów. Geneza, znaczenie i perspektywy dla arteterapii [Mysteries of Labirynths. The Origins, Meaning and Perspectives in Art Therapy]. Kultura - Społeczeństwo - Edukacja nr 2(10) 2016, Poznań 2016, pp. 295-304, Adam Mickiewicz University Press. ISSN 2300-0422. DOI 10.14746/kse.2016.10.22.

This article is inspired by private research conducted by the author over the past few years. The study involved more than 600 students of WSE UAM in Poznan and WP WSPiA in Poznan. The article describes metaphor of the labyrinth. Labyrinth and its metaphor is known in cultures and religions for more than 4,500 years and is still strongly present in many. The main purpose of this study is to explore and show psychological, cultural and philosophical significance and importance of the labyrinth and its metaphors in the modern world - especially among young adults. The article is also a prelude to a discussion about the use of the metaphor of the labyrinth in therapy by art - especially horticultural therapy.
\end{abstract}

\section{LABIRYNT}

Życie w pozornej swej przejrzystości,

Jest labiryntem zawiłości.

Najgrubsza linia to linia życia,

Płynie przez kartkę w celu odkrycia:

Co jest na końcu, co nas tam czeka,

A droga linii jest tak daleka.

Linia ta płynie przez barw odcienie,

Jak przez naszego życia istnienie.

Czasami życie jest sielankowe,

Wtedy kolory są wprost różowe.

W tym samym czasie burzy fiolety

Niosą niepokój, strach i podniety. 
Jest tak od zawsze dla równowagi, Radość się zmienia w stany powagi, A ścieżki boczne, spraw zawiłości

Kręcą się, wiją, czasami kończą. Potem $\mathrm{z}$ innymi nagle się łączą. Tak życie płynie tworząc labirynt Spraw i przypadków bardzo zawiłych. ${ }^{1}$

\section{Geneza Labiryntu}

Pojęcie labiryntu - sieci splątanych dróg prowadzących do umieszczonego w środku celu - pojawiało się w różnych znaczeniach w niemal każdej znanej kulturze (Hobhouse, 2005: 299). Zarówno jego metafora, jak i fascynacja namacalnymi labiryntami jest obecna w świadomości ludzi od zarania dziejów. W XII wieku zaczęto zakładać dobrze znane już w starożytności strzyżone labirynty roślinne. Ogromnie popularne były one w renesansowych ogrodach XVI-wiecznych Włoch. To właśnie wtedy ponownie stały się one w Europie sposobem na ciekawe i refleksyjne zagospodarowanie wolnego czasu². Labirynt już tysiące lat temu stał się wymownym, często używanym symbolem. Teraz, na początku XXI wieku, jak słusznie zauważa Hermann Kern, jego symbolika przemawia na nowo, a „(..) zjawisko zainteresowania motywem labiryntu przetacza się niczym fala przez współczesny świat (..."3. Historie labiryntów to uniwersalne opowieści o wzruszeniu i odwadze, o nowych drogach na nieznanym obszarze, o niebezpieczeństwach, zagubieniu siebie, śmierci, a także o szczęściu i odnalezieniu nadziei (Hohmuth, 2003: 13).

Od momentu, w którym w mojej głowie zrodził się pomysł Labiryntu Rosnacych Tajemnic ${ }^{4}$ i fascynacja formą rosnącego żywego labiryntu, starałem się sprawdzić, czym labirynt w ogóle, jako symbol, znak czy metafora jest dla ludzi. Badania i wywiady oraz rozmowy prowadzałem przez kilka lat, wzięło w nich udział blisko 600 osób, wśród których znajdowali się studenci i studentki różnych roczników Wydziału Studiów Edukacyjnych na Uniwersytecie im. Adama Mickiewicza w Poznaniu i Wydziale Pedagogicznym w Wyższej Szkole Pedago-

\footnotetext{
${ }^{1}$ Wypowiedź pisemna osoby badanej. Do wypowiedzi dołączone było różowo-fioletowe zdjęcie z czarnym labiryntem. Za: Stępak, 2012: 52.

${ }^{2}$ Więcej na ten temat w: Samson, 2012.

${ }^{3}$ Tłum. własne: a renewed interest in labyrinths has swept the globe. Kern, 2000: 311.

${ }^{4}$ Instalacja pt. Labirynt Rosnących Tajemnic jest formą żywej rzeźby, którą zacząłem tworzyć w 2005 roku w Poleskim Ośrodku Kultury w Łodzi. Ze względu na to, że jako tworzywo artystyczne użyłem żywych roślin i wikliny, jest to niesamowita, wymagająca ciągłej troski forma artystyczna tworząca „żywy”, rosnący labirynt.
} 
giki i Administracji im. Mieszka I w Poznaniu. Zadaniem, które zadawałem studentom, było pozornie proste projekcyjne pytanie: Czym dla mnie jest labirynt? Odpowiedź można było skonstruować w dowolnej wybranej formie tekstowej, graficznej lub innej w zależności od preferencji studentów. Zależało mi na tym, aby odpowiedź była szczera i przedstawiała to co jako pierwsze kojarzyło się danej osobie $\mathrm{z}$ hasłem labirynt. W swoich odpowiedziach większość studentów odwoływała się do sfery psychicznej funkcjonowania człowieka w świecie i społeczeństwie oraz do trudów i zawiłości życia codziennego. Niektórzy jednak tworzyli własne, niezwykle oryginalne pomysły interpretacji tego pojęcia. Ta różnorodność wypowiedzi świadczy o sile symboliki i oddziaływaniu jakie metafora labiryntu posiada we współczesnym świecie. W niniejszym referacie będę swobodnie wplatał fragmenty wypowiedzi badanych osób w prowadzoną refleksję teoretyczną ${ }^{5}$.

Od ponad pięciu tysięcy lat labirynt jest tajemniczym symbolem poszukiwania środka życia - drogi do szczęścia i spełnienia. Śmiało można napisać, że w takim jego rozumieniu wszystko może stać się labiryntem. Także uczucia, myśli, pragnienia, poszczególne okresy życia, relacje międzyludzkie, kryzysy psychiczne. Każdy z tych aspektów życia stawia przed nami pewne wyzwania, które możemy podjąć pokonując napotkane przeszkody czy pułapki i w ten sposób dotrzeć do upragnionego celu. Ów środek na początku stanowiący cel naszej podróży, staje się wówczas nowym punkiem wyjścia do dalszych poszukiwań. Przeistacza się w moment przełomowy na ścieżce życia, osiągając który, rozwiązujemy kryzys psychiczny i wkraczamy na kolejny - inny - poziom rozwojowy ${ }^{6}$. Początkiem i bramą do nowego labiryntu istnienia. Ten twórczy aspekt labiryntu wydaje się szczególnie podkreślać Pani Kamila w swojej wypowiedzi:

Labirynt to miejsce, gdzie znajduje się wiele korytarzy bądź dróg. Labirynt to zagadka, trudno jest znaleźć drogę, która wiedzie do celu. Dla mnie labiryntem jest ludzkie życie. Człowiek codziennie staje przed wyborem, którą drogą ma iść. Tak jak w labiryncie, wybór odpowiedniej drogi nie jest łatwy. Często okazuje się, że droga, którą wybraliśmy jest „ślepa”. Wtedy musimy się wrócić i od nowa planować nasze życie. Każdego dnia, błądząc po meandrach życia, uczymy się czegoś nowego. (Stępak, 2012: 49)

Analogicznie do procesu twórczego - widząc efekt końcowy swojej pracy, często odczuwam pewien niedosyt procesu twórczego. Moment ten lub samo jego znaczenie przeistacza się wówczas $\mathrm{w}$ dalsze jego doskonalenie lub początek

\footnotetext{
${ }^{5}$ Wszystkie wykorzystane $\mathrm{w}$ referacie wypowiedzi osób badanych są zaprezentowane w możliwie takim samym układzie strukturalnym w jakim je otrzymałem (przy części wydaje się to istotne). Wszystkie można znaleźć w mojej nieopublikowanej rozprawie habilitacyjnej: J. Stępak, Labirynt Rosnących Tajemnic, maszynopis pracy habilitacyjnej, Poznań 2012.

${ }^{6}$ Więcej na ten temat w: Erickson, 2004.
} 
realizacji zupełnie nowego pomysłu. Pozorne zakończenie pracy nad jednym dziełem przechodzi niekiedy bardzo płynnie, niemal niewidocznie, w pracę nad kolejnym. Dzieje się tak właśnie na skutek oddziaływania czy swoistej inspiracji płynącej z etapu, do którego dotarliśmy - ze środka labiryntu, będącego, jak się okazuje, niekoniecznie celem ostatecznym, lecz jednym z wielu celów, jakie realizujemy w swoim życiu. Ten aspekt szczególnie uwidocznił się w wypowiedzi Pani Joanny, która w odpowiedzi na otwarte pytanie badawcze napisała poniższy biały wiersz podkreślając przesuwalność i swoisty wędrowniczy charakter życia postrzeganego przez pryzmat metafory labiryntu:

\section{LABIRYNT}

Pośród jego szarych ścian kryje się nieskończoność. Mrokiem spowity świat przytłacza nas co krok.

To właśnie tu każdy gubi się, by znów odnaleźć drogę do nieznanego. Niekoniecznie właściwą, ale z pewnością łatwiejszą.

Tuż za zakrętem, tam gdzie ciemność rozdziera światło, stoi człowiek.

Samotny, utęskniony wypatruje znaków, Bo tylko cud może sprawić, że znów powróci nadzieja, Ten z pozoru oczywisty trop tylko czeka by nas zmylić, by znów doprowadzić do niechybnej zguby.

Cień przeznaczenia. Swym widmem próżności owładnął już ostatnią cząsteczkę ludzkości.

Cień przeznaczenia. Nie dopuść, by dopadł cię by znieść.

Ledwie światło przebije się przez jego grube mury, by potem natychmiast zniweczyć wszelkie próby ludzkiego działania.

Zwodzi i oszukuje. Prowadzi do celu, który potem okazuje się być niczym innym, niż tylko marną ułudą, zaledwie namiastką oczekiwanego celu. I tylko czas jest w stanie wyprowadzić nas stąd.

Bo z czasem LABIRYNT ŻYCIA staje się prostą ścieżką przez las. (Stępak, 2012: 50)

Każdego dnia stoimy w drzwiach do nowego czasu. Przed nami leży labirynt przyszłości - inny dla każdego z nas. Czy uda nam się znaleźć drogę w zawiłych ogrodach technologii? Czy nie zagubimy się w cybernetycznych przestworzach? Kto przeprowadzi nas przez labirynt nadchodzącego świata? Gdzie znajdziemy nić Ariadny, która pozwoli się nam zorientować na drodze do przyszłości? Może odpowiedzi trzeba szukać tam, gdzie się jej najmniej spodziewany - w naszych marzeniach i fantazjach, w sile intuicji i kreatywności, w grach i łamigłówkach, garażach i warsztatach (Hohmuth, 2003: 8).

Tak rozumiane labirynty stają się drzwiami wejściowymi do nowych odcinków życia i do własnego wnętrza. To właśnie w labiryncie leżą siły odnowy dla ciała i duszy. Terapeutyczna siła labiryntu ukazuje się przy resocjalizacji więźniów, w opanowaniu stresu, terapii raka i każdej innej trudnej sytuacji życiowej (Hohmuth, 2003: 10). Labirynt prowadzi do wewnętrznego spokoju. Kto przemierza tę drogę w stanie uduchowienia, kto udaje się świadomie $\mathrm{z}$ otwartą duszą 
do labiryntu, dla tego labirynt stanie się miejscem odnalezienia samego siebie. Labirynt kieruje się zasada dróg okrężnych ${ }^{7}$. Ofiarowuje on zadumę, wymaga opóźnienia bezpośredniej reakcji na podniety, nadaje sens niezliczonym sytuacjom i momentom na drodze do celu - chorobom, kryzysom, zwątpieniom (Hohmuth, 2003: 12). Jego idea przeciwstawia się zasadzie przyjemności sformułowanej przez Freuda ${ }^{8}$. Jego siła tkwi w tym, że zatrzymuje nas i niejako zmusza do refleksji, abyśmy mogli odnaleźć siłę, która pozwoli wznieść się ponad wszystko nie zważając na przeciwności losu. Labirynt jest szkołą powolności. Im więcej idący labiryntem przemierza okrążeń, tym głębsze staje się poznanie i zrozumienie otaczającego go świata. Każdy zwrot w labiryncie życia ofiarowuje nam nowy kierunek marszu i nowe spojrzenia na tajemnicę jego środka (Hohmuth, 2003: 12). Ten element wędrówki i problematycznych kierunków oraz wyborów, z którymi trzeba się zmierzyć, uwidocznił się w wypowiedzi Pani Małgorzaty:

Życie jest jednym skomplikowanym i nieodgadnionym labiryntem. Tak jak w labiryncie, tak i w życiu zdarzają się sytuacje bez wyjścia. To po prostu ludzka bezsilność, bezradność. Życie to kręte, pogmatwane drogi labiryntu. Każdy z nas powinien mieć jakiś cel w życiu i starać się dotrzeć do niego, pokonując trudności, aby spełnić swoje nadzieje. Ileż to razy błądzimy, nie mogąc znaleźć właściwej drogi. (Stępak, 2012: 50)

Podążanie krętymi, nieznanymi ścieżkami labiryntu może napawać - i nierzadko rzeczywiście napawa - strachem. Idących labiryntowymi drogami ogarnia często lęk. Jest to lęk przed trudnościami, jakie mogą napotkać na swojej drodze, lęk przed nieodnalezieniem środka, a tym samym niedotarciem do celu, lęk przed nieznanym. Ten lękowy aspekt labiryntu szczególnie podkreślała Pani Marlena:

Labirynt zawsze był i będzie pułapką. Tysiąc wejść i tylko jedno wyjście. Tylko jedno zadowalające rozwiązanie. W labiryncie nie liczy się „prawie mi się udało”. Udało mi się lub nie. Osiągnąłem cel, lub poniosłem porażkę. (Stępak, 2012: 51)

Jednak warto zauważyć, że obawy te są zupełnie niepotrzebne. Prawdziwy labirynt jest bowiem wielkim symbolem pewności. Jest w nim tylko jedna droga, która zawsze prowadzi do środka, a przesłanie każdego labiryntu brzmi: Nie możesz zginąć w drodze do środka! Na końcu nieodgadnione ścieżki twojego życia okażą się wzorem pełnym sensu. A uczucie sensownego odkrywania świata i siebie samego jest czymś niezwykłym?

\footnotetext{
${ }^{7}$ Zgodnie z którą dłuższa droga umożliwia lepsze zrozumienie samego siebie i rozpatrywanych problemów. Więcej na ten temat w: Kern, 2000.

${ }^{8}$ Więcej na ten temat w: Freud, 1994.

${ }^{9}$ Więcej na ten temat w: Kern, 2000 oraz w: Czapiga, 2013.
} 
Labirynt optymistycznie wyraża ziemię jako miejsce życia człowieka. Kto się uda w tę drogę, dowie się, że ziemia jest cudowna w całej swej okazałości. Zrozumie, że można polegać na porządku rzeczy, poddać się losowi, podążyć za swoimi marzeniami, a na końcu swej drogi każdy człowiek dochodzi pomimo wszelkich pomyłek i zawirowań do swojego celu (Hohmuth, 2003: 9).

Podczas gdy w rejonie Morza Śródziemnego obraz labiryntu przetrwał tylko jako rysunek, w północnej Europie, a szczególnie w Szwecji, jego podstawowa namacalna - forma zachowała się $\mathrm{w}$ wielu miejscach. Nie bez przyczyny określenie labirynt zostało w Szwecji wprowadzone dopiero w XVI wieku. Chociaż $\mathrm{w}$ archeologii używane jest jako pojęcie podstawowe, to dużo starsze są jednak określenia ludowe jak trojeborg lub jungfrudans. Co szczególnie ciekawe, w swojej etymologii wskazują one - podobnie jak określenia pochodzące $\mathrm{z}$ obszaru Morza Śródziemnego - na miasto Troja i wykorzystanie labiryntu jako miejsca tańca i celebracji życia (Hohmuth, 2003: 26).

Początkowo labirynt był miejscem o magicznych właściwościach, symbolicznym miejscem kultu oraz mitologicznych zdarzeń. Taniec dziewic - to jeden ze zwyczajów ludowych ściśle związany z labiryntami. Owe rytuały aż do XX wieku odbywały się w labiryntach w okresie pomiędzy Wielkanocą a latem. Jedna młoda kobieta stawała $\mathrm{w}$ centrum labiryntu, a pozostałe sunęły ku niej od wejścia labiryntu w przeróżnych rytmach tanecznych, aby ją wyzwolić z wyobrażonej twierdzy. Poza tym wędrówka po labiryncie miało służyć różnym magicznym celom. Rybacy twierdzili, że wpływają w ten sposób na pogodę i połowy albo że dzięki temu będą chronieni przed niebezpieczeństwami. Południowi Szwedzi sądzili natomiast, że obronią się tak przed wilkami i gnomami (Hohmuth, 2003: 27).

Z czasem w kulturze europejskiej labirynt stał się również metaforą tajemnicy i nierozwiązywalnej sytuacji. Źródłem tego archetypu stał się mit o Minotaurze. Labirynt willi d’Este $\mathrm{w}$ Tivoli był hołdem właśnie dla tego mitycznego labiryntu, z którego Tezeusz wydostał się dzięki nici Ariadny. Natomiast francuskie labirynty czasami nazywano dedales, od imienia Dedala, legendarnego twórcy kryjówki człowieka-byka ${ }^{10}$.

Samo słowo labirynt pochodzi od starogreckiego labar - jaskinia, kopalnia o wielu korytarzach, lub od labirion - chodnik wydrążony w ziemi przez kreta. Motyw labiryntu symbolizuje szeroki w swoim znaczeniu i wieloetapowy proces wtajemniczenia. Jest to również metafora wędrówki duszy do krainy umarłych (Hohmuth, 2003: 299).

Tajemnica jest nieodłącznym elementem ludzkiej egzystencji. Można się w nią zagłębiać i rozpatrywać pod różnymi aspektami egzystencjalno-poznaw-

\footnotetext{
${ }^{10}$ Więcej na temat mitu w: Parandowski, 1989.
} 
czymi. Są ludzie, którzy mogą żyć obok tajemnicy, bowiem odpowiedź na pewne pytania jest im obojętna, wolą nie zagłębiać się w nieznane. Są jednak i tacy, dla których rozwiązanie zagadki i odkrycie tajemnicy jest istotne, a niekiedy nawet niesamowicie ekscytujące. To właśnie ci drudzy po jedynie krótkiej chwili zawahania, żądni przygód i odkrywania tego co nieodkryte, podążają w głąb labiryntów. Warto $\mathrm{w}$ tym miejscu podkreślić silny związek metafory labiryntu $\mathrm{z}$ inną metaforą pochodzącą $\mathrm{z}$ obszaru morza śródziemnego. Metaforą zagadki, wieszczenia, z której zrodziła się filozofia grecka. Ta metafora zagadkowości, życia jako labiryntu i labiryntu jako zagadki znalazła swój wyraz w wypowiedzi Pani Angeliki:

...galaktyka, Mleczna Droga. Po pierwsze istnieje podobieństwo wizualne - galaktyka, w której znajduje się nasz układ słoneczny ma kształt spirali (jak labirynt) zbudowanej z pyłu, gwiazd i planet. Po drugie labirynt kojarzy mi się z czymś nieodkrytym, do końca niepoznanym, nieprzewidywalnym. Człowiek nigdy nie może być pewien co go tam spotka. (Stępak, 2012: 51)

Labirynty są symbolami zmiany, a tym samym symbolami świata, w którym żyjemy - jest to bowiem świat dynamiczny, świat ciągłych przemian. Dlatego sieci, jak Internet, często porównywane są do labiryntu. Nie jest to jednak do końca słuszne porównanie. Internet bowiem nie ma środka, który jest najważniejszym niemal elementem labiryntu (Hohmuth, 2003: 13). I nie ma jednej ścieżki, drogi wejście i wyjścia $\mathrm{z}$ niego. Jest więc pozbawiony najważniejszego symbolicznego jak i rzeczywistego elementu labiryntu - bramy.

\section{Brama}

Każdy labirynt wyposażony jest przynajmniej w jedną bramę wejściową, przejście przez którą oznacza wkroczenie do innego świata i rozpoczęcie podróży. Zresztą ta rola nadal ma odzwierciedlenie w bramach - zwłaszcza ogrodowych. Tworzy się je po to, by wywierały silne wrażenia na odwiedzających. Ich funkcja diametralnie zmieniała się podczas wojen lub zamieszek. Wówczas wszelkiego rodzaju bramy traktowane były jako element służący do obrony przed nieprzyjacielem (Conran, Pearson, 2000: 60). Jako element odgrodzenia się od Innego i inności. W dzisiejszych czasach brama to najczęściej duże ozdobne wejście do kościoła, dziedzińca czy posiadłości. Z kolei metaforyczne znaczenie tego słowa daleko nie odbiega od jego dzisiejszego zastosowania. Słowo brama według starosłowiańskiego słownika pochodzi od słowa bronić. Jego symbolika przechodzi więc od bramy symbolizującej przejście do lepszego świata, wejście do nieba, poprzez otwartą bramę będącą metaforą gościnności i zaproszenie, aż po za- 
mkniętą bramę symbolizującą odgrodzenie, zakaz, a nawet strach lub z drugiej strony właśnie ową ochronę (Ligendza, 1993).

Gdy wypowiadam słowo brama, w oczywisty sposób nasuwa się mi skojarzenie dotyczące wnętrza, do którego ona prowadzi, oraz samego momentu przejścia $\mathrm{z}$ jednego miejsca do drugiego. Jest to bowiem pewne dosłowne jak i metaforyczne odgrodzenie czegoś, co znajduje się przed i $z a$ bramą. Owo przejście każdy zgodnie $\mathrm{z}$ własnym doświadczeniem i usposobieniem może interpretować na zupełnie odmienny sposób. Dla jednych bywa ono nacechowane pozytywnie. Wówczas może wiązać się z zakończeniem starych przykrych spraw, utrapień i problemów. Może oznaczać symboliczne rozpoczęcie nowego życia. To od nas wówczas zależy, którą ścieżkę labiryntu wybierzemy po przejściu przez bramę i jakie będą nasze dalsze losy. Niektórych natomiast owo przejście napawać może strachem. Lęk związany z metaforyką labiryntu przejawiał się w wielu wypowiedziach. Podkreśliła go między innymi Pani Anna:

Przemierzając nasze życie, powinniśmy pamiętać, że każdy nasz krok pozostawia ślad na drodze, jaką pokonujmy. Być może to wina naszych śladów, może sami zadeptaliśmy sobie drogę, co uniemożliwia nam znalezienie tego jedynego wyjścia. (Stępak, 2012: 51)

Nie nic zaskakującego $\mathrm{w}$ tym, że przeraża nas niewiadoma czekająca po przekroczeniu niewidzialnej granicy wyznaczanej przez bramę. Nowy, nieznany świat zawsze stwarzał atmosferę niepewności, wywołując niekiedy silny lęk, odbierający zdolność do jakiejkolwiek aktywności. Zarówno pierwsze, jak i drugie podejście do symboliki bramy i przejścia przez nią oraz wkroczenia w nieznane zaułki labiryntu są niezwykle istotne. Obydwa są nieodłącznym elementem wędrówki przez labirynt (i przez życie) jak słusznie podkreśla Pani Barbara:

Dla mnie labirynt to przede wszystkim życie. Życie niejednostajne i wolne od nudy i rutyny. Nigdy nie wiemy, co przyniesie jutro, które często jest zgubne i fałszywe jak w labiryncie. Którąkolwiek drogę byśmy wybrali, zawsze jest ryzyko, że będziemy musieli zaczynać wszystko od nowa. W życiu tak jak w labiryncie, spotykają nas sytuacje pozytywne (zmierzamy we właściwym kierunku) oraz negatywne (błądzimy, nie wiemy, co robić, potrzebujemy pomocy). Życie usłane jest przeszkodami, które musimy pokonać, by dotrzeć do upragnionego celu. Ważne, by mieć w życiu jakiś cel i nie poddawać się, bo może doprowadzić to do rychłej zguby. (Stępak, 2012: 51)

W pierwszym przypadku bowiem zyskujemy poczucie mocy i pewności siebie, a także sprawstwa i poczucia kontroli nad własnym życiem. W drugim przypadku natomiast wszystko to tracimy sparaliżowani strachem przed nieznanym.

Przejście przez bramę i wkroczenie w świat labiryntu to intensywne przeżycie dla każdego wędrowca. Wymaga od niego siły, wytrwałości i odwagi, a skutki jakie za sobą niesie mogą być zaskakująco pozytywne. Przełamanie lęku i stra- 
chu, pokonanie granic własnych możliwości lub wyjście naprzeciw przygodzie i podążenie $\mathrm{w}$ nowe i nieznane jest tym, co może uczynić każdego człowieka silniejszym. Pozwala mu także spojrzeć na siebie, innych ludzi i otaczającą rzeczywistość z zupełnie innej strony i nadać wszystkiemu nowe znaczenie zgodne $z$ kierunkiem swojej mentalnej wędrówki. Bardzo intuicyjnie wyraziła ten aspekt Pani Izabela w swojej wypowiedzi:

W dzisiejszym świecie panuje chaos, wielość racji, zachowań, postaw. Zostały rozmyte granice dobra i zła, człowiek został wyrwany z pewności tego kim ma być, a kim mu być nie wolno. W konsekwencji ludzie czują się zagubieni, zdezorientowani i stoją przed wyborem wielu możliwych tożsamości, można powiedzieć, że epoka nowoczesności wymusza $\mathrm{w}$ jakiś sposób ciągłe poszukiwanie swej tożsamości, eksperymentowanie $\mathrm{z}$ nią. Każdy z nas stoi u progu „labiryntu”, jeśli go przejdzie, osiągnie sukces - dojrzałość, stabilność emocjonalną, umiejętność radzenia sobie z przeciwnościami i problemami. (Stępak, 2012: 53)

Jak łatwo zauważyć, teoretyczne refleksja na temat miejsca oraz roli metafory labiryntu wydaje się doskonale odzwierciedlać w wypowiedziach badanych osób. Dla których labirynt jest przede wszystkim wewnętrznym labiryntem istnienia. Labirynt jako miejsce zagrożenia, ale i paradoksalnie bezpieczeństwa (bo zatrzymania, ułamku stałości w zmiennej ponowoczesności) staje się metaforą kluczem do psychiki człowieka w dobie kryzysu podstaw ontologicznych stanowiących gwarant stałości tożsamości ${ }^{11}$. Ostatecznie, jak zauważa Pani Justyna:

Labirynt jako psychika ludzka, ludzkie serce, albo raczej droga prowadząca do jego wnętrza. Labirynt jako zagadka, jako problem. (...) Prawdziwym labiryntem jest ludzkie życie, które mimo upływu tysięcy lat nadal pozostaje niezgłębioną tajemnicą. (Stępak, 2012: 51)

\section{Podsumowanie}

Wydaje się więc, że zarówno idea labiryntu, bramy, jak i ich namacalne inkarnacje w postaci żywych ogrodów mogą, miały i coraz częściej znajdują lub powinny znajdywać zastosowanie w praktyce arteterapeutycznej. Ostatecznie terapia przez sztukę „(...) w szerokim znaczeniu obejmuje muzykoterapię, choreoterapię, biblioterapię oraz działania terapeutyczne przy pomocy teatru, filmu, sztuk plastycznych, takich jak malarstwo, rzeźba, grafika" (Szulc, 1994, cyt. za: Galińska, 1989: 73-75). W takim kontekście rodzi się stosunkowo nowy w Polsce i jeszcze mało eksplorowany obszar pomocy terapeutycznej - hortiterapii ${ }^{12}$. Wydaje się

\footnotetext{
${ }^{11}$ Więcej na temat rozpadu „Ja” we współczesnym świecie w: Rowman, Cooper, 2008.

${ }^{12}$ Zamiennie stosuje się również określenia ogrodoterapia i ogrodolecznictwo.
} 
ona jedną z najnaturalniejszych i głęboko zakorzenionych w kulturze i doświadczeniu społeczno-historycznym - praktyk terapeutycznych. Bo skoro (za Panią Małgorzatą) „Jedyną radą na wyjście z labiryntu jest bycie sobą" (Stępak, 2012: 49). To dlaczego nie poszukiwać siebie w konfrontacji ze stanowiącym stosunkowo mniejsze zagrożenie dla poczucia stałości i tożsamości zewnętrznym labiryncie ogrodu? Jest on tym bardziej terapeutycznie ciekawy, że nasuwa refleksyjne myśli o wewnętrznej niestałości. Paradoksalnie umożliwiając tym samym konfrontacje $\mathrm{z}$ wewnętrznym lękiem $\mathrm{w}$ bezpiecznym otoczeniu. $\mathrm{W}$ przestrzeni, która zapewnia spokój, wymaga dbania o nią, a jednocześnie nie ucieknie, nie zniknie, zagwarantuje stałość i widoczność efektów pracy, troski i miłości, którą trzeba jej okazywać.

\section{Literatura}

Conran T., Pearson D. (2000). Nowoczesne Ogrody. Warszawa.

Czapiga M. (2013). Labirynt: inicjacja, podróż i zbłądzenie. Figura ludzkiego losu w kulturze europejskiej. Wrocław.

Erikson E.H. (2004). Tożsamość a cykl życia. Poznań.

Freud Z. (1994). Poza zasada przyjemności. Warszawa.

Galińska E. (1989). Muzykoterapia jako jedna z form terapii poprzez sztukę. „Zeszyt Naukowy Akademii Muzycznej” nr 48, s. 73-75.

Hobhouse P. (2005). Historia Ogrodów. Warszawa.

Hohmuth J. (2003). Labyrinthe. Irrgarten, Geosasion. Munchen.

Kern H. (2000). Through the Labyrinth: Designs and Meanings over 5,000 Years. New York. Ligendza M. (1993). Mały słownik zwrotów i pojęć religijnych. Warszawa.

Parandowski J. (1989). Mitologia. Wierzenia i podania Greków i Rzymian. Poznań.

Rowman J., Cooper M. (2008). Jekyll i Hyde. Wielorakie Ja we współczesnym świecie. Gdańsk. Samson A. (2012). Locus Amoenus: Gardens and Horticulture in the Renaissance. New Jersey. Stępak J. (2012). Labirynt Rosnących Tajemnic, maszynopis pracy habilitacyjnej, Poznań.

Szulc W. (1994). Kulturoterapia - wykorzystanie sztuki i działalności kulturalno-oświatowej w lecznictwie. Poznań. 